\author{
A. Nagy, J. Kundrák, Miskolc, Hungary
}

\title{
ANALYSIS OF THE CHANGE IN ROUGHNESS ON A FACE-MILLED SURFACE MEASURED EVERY $45^{\circ}$ DIRECTION TO THE FEED
}

\begin{abstract}
In this article, we analyze the difference (inhomogeneity) of the roughness values measured on a nonalloy carbon steel surface milled with a parallelogram-shaped $\left(\kappa_{r}=90^{\circ}\right)$ insert as a function of the the tool movement direction and the relative position of the examining points on the workpiece surface. The characteristic distribution of roughness and the magnitude of the deviations were examined by measuring at selected points along several planes on a surface characterized by the movement conditions of the workpiece and the symmetrically arranged tool perpendicular to the machined surface, which formed double milling marks. The selected points mark the lines with specified inclinations with respect to the feed direction, and their measured values were compared. In these directions, the magnitude of the difference in roughness measures was obtained.

Keywords: face milling; surface roughness; distribution of roughness.
\end{abstract}

\section{INTRODUCTION}

Face milling is one of the most widely used methods in the industry for machining flat surfaces, due to its high productivity, the high quality surface available and the wide use of the parts machined in this way. One of the conditions for achieving good quality is to create a topography that meets the operational requirements.

For cutting with a tool having defined edge geometry, a periodic topography is obtained, while for a cutting with an abrasive tool, a random topography is created. The theoretical impression of a tool edge having defined geometry is determined by the cutting edge angles and the magnitude of the feed rate used, measured in the tool reference plane. The more complex the motion conditions are (and the more the chip cross-section changes) in the chip removal, the more varied the theoretical profile will be, so it is justified to analyze the surface topography and explore its characteristics.

Various surface textures are created under different geometric and kinematic conditions, for which the standard ANSI Y14.36-1978 [1] also shows an example. Unlike those examples a more complex topography is created with face milling. This was analyzed by Kundrák and Felhő using a method based on CAD modeling [2], showing how to determine the roughness characteristics of the theoretical surface of a tool having defined edge geometry and the possibility of estimating and designing the desired roughness values. The significance lays in the fact that the theoretical roughness values of the face milled surface can be determined in directions other than the feed, as well as at any point on the surface. By using this, it was shown by measurements at three different locations that the roughness of the face milled surface varies from position to position [3]. 
In another of their articles [4] they described a method for describing the relationship between theoretical and experimental roughness indices using a defined edge geometry tool (stationary and rotary tool).

Felhö et al. [5] presented an analytical model and a test method for inserts with two different edge geometries to estimate surface roughness values in advance.

Arizmendi et al. developed another method for creating face milling surface topographic models. In one of their articles [6] the model was developed by analytical prediction of surface topography. This allows simulation analysis of roughness profiles created in different planes of the workpiece surface.

The values of experimentally determined roughness parameters are influenced by several factors in addition to the determinate characteristics of the theoretical values, the effect of which is widely studied. Chuchala et al. [7] studied the effect of the depth of cut and the number of passes on the roughness on an aluminum alloy, which was measured symmetrically arranged along the path of the milling tool axis. There was a difference in the nature of the changes in the values of the 2D and 3D roughness parameters. Furthermore, it was found that the average values of the roughness parameters were the highest on the surface part produced by down-milling.

Pham et al. [8] examined the contact length between the tool edge and the chip, the amplitude of the workpiece vibration, and the average roughness in face milling with a carbide insert on A6061 aluminum alloy. The results showed that the contact length, the degree of vibration and with it the roughness decreased with increasing cutting speed, while they increased with increasing feed rate and depth of cut.

Gocke [9] studied the effect of cutting speed and feed on surface roughness and tool wear in the face milling of martensitic stainless steel. It was found that the roughness is mainly affected by the feed and the wear by the cutting speed. Their intensity and nature differed for different inserts.

Bruni et al. [10] analyzed the effect of the lubrication-cooling condition on the roughness on stainless steel, considering the cutting time. It was found that in the case of wet cutting and MQL technique, the roughness decreased with time, while in the case of dry machining it increased slightly.

Sai et al. [11] optimized the cutting parameters to achieve the least roughness in up-face milling, during which the optimal cutting speed was determined.

Pimenov et al. [12] studied the effect of the relative position of the workpiece and the milling tool on the surface roughness. It was found that from the machined surface having an up-milled dominant part to a down-milled overwhelming part, the roughness measured in the direction of the feed rate showed a gradual increase.

The above analysis also shows that the theoretical and the real roughness values measured on the topographies of the machined surfaces may be different due to additional factors influencing the cutting process. Our goal in face milling is to explore the difference in roughness values measured at different points on the surface, in other words, the roughness inhomogeneity of the surface. This was previously addressed by 
Nagy and Kundrak [13], where the change in roughness of the face milled surface was investigated by roughness measurements parallel to and perpendicular to the feed direction. In experiments it was shown that the values of the roughness parameters on the surface vary depending on the measurement direction and location. In symmetrical milling, the roughness values were influenced by which side of the symmetry plane the cutting takes place on. The difference was explained by the effect of up- and downmilling.

In this paper, we deal with the analysis of roughness values measured at points fitted to lines parallel to the feed direction and at $45^{\circ}$ or $90^{\circ}$ to the direction of feed.

\section{EXPERIMENTAL AND MEASUREMENT CONDITIONS}

\subsection{EXPERIMENTAL CONDITIONS}

Machine tool: PerfectJet MCV-M8 vertical milling center

Workpiece material: normalized $\mathrm{C} 45$ unalloyed steel

Machined surface geometry: $58 \mathrm{~mm}$ width, $50 \mathrm{~mm}$ length

Cutting tool: Sandvik R252.44-080027-15M face milling head $\left(D_{t}=80 \mathrm{~mm}\right)$

Cutting insert: one Sandvik R215.44-15T308M-WL parallelogram-shaped coated carbide insert $\left(\kappa_{\mathrm{r}}=90^{\circ}, \gamma_{\mathrm{o}}=0^{\circ}, \alpha_{\mathrm{o}}=11^{\circ}, \mathrm{r}_{\varepsilon}=0.8 \mathrm{~mm}\right)$

Cooling-lubrication: with dry cutting conditions

Cutting strategy: The surface was machined to its full width with a symmetrical setting. The edge of the tool with an axis perpendicular to the milled surface formed double milling marks on the surface, thus the front-cutting and back-cutting edge traces were also visible.

Cutting data: the cutting speed was $\mathrm{v}_{\mathrm{c}}=300 \mathrm{~m} / \mathrm{min}$, the feed rate per tooth was $\mathrm{f}_{\mathrm{z}}=0.3 \mathrm{~mm} /$ tooth, the depth of cut was $\mathrm{a}_{\mathrm{p}}=0.8 \mathrm{~mm}$

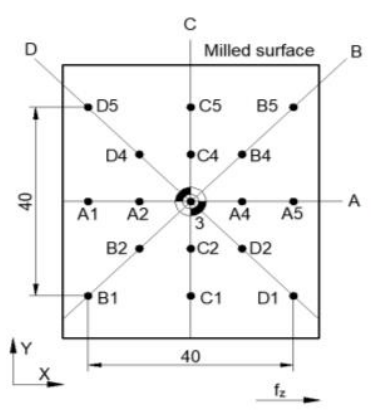

a

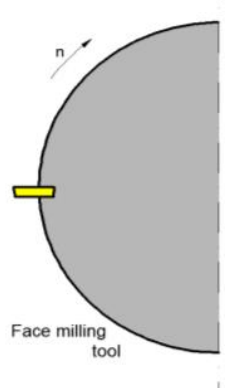

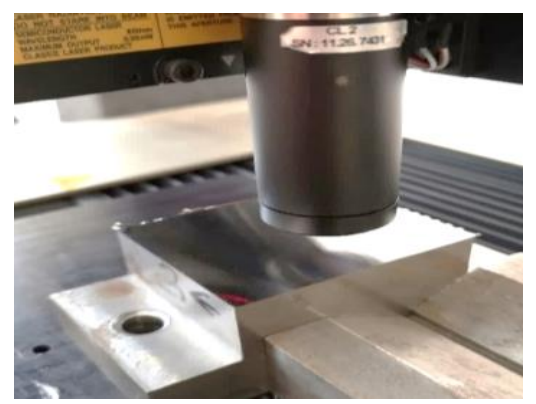

b

Figure 1 - Analysis system of surface inhomogeneity (a), the specimen and the measuring probe (b) 


\subsection{ROUGHNESS MEASUREMENT CONDITIONS}

Measuring equipment: AltiSurf 520 three-dimensional surface topography measuring instrument, using a confocal chromatic probe (Fig. 1b)

Evaluation software: AltiMap Premium

Measurement strategy: Measuring points were recorded on an area of $40 \times 40 \mathrm{~mm}^{2}$ on the machined surface so that the corresponding points designate defined examining planes. The position of the planes relative to the feed direction is shown in Fig. 1a and the positions of the points are given in Table 1, where the zero point is fitted to $\mathbf{A 3}=\mathbf{B 3}=\mathbf{C 3}=\mathbf{D 3}=\mathbf{3}$. Accordingly, line $\mathbf{A}$ is the symmetry plane of the surface, where the tool axis moves in the feed direction, and the other planes are rotated at a defined angle from $\mathbf{A}\left(\mathbf{B}-45^{\circ}, \mathbf{C}-90^{\circ}, \mathbf{D}-135^{\circ}\right)$. At each point, the roughness was measured parallel to and perpendicular to the feed direction according to the requirements of ISO 4287:1997; the measurement length was $4 \mathrm{~mm}$, and the cut-off length was $0.8 \mathrm{~mm}$.

Table 1 - Positions of measurement points

\begin{tabular}{|c|c|c|c|c|c|}
\hline Point & $\mathrm{X}[\mathrm{mm}]$ & $\mathrm{Y}[\mathrm{mm}]$ & Point & $\mathrm{X}[\mathrm{mm}]$ & $\mathrm{Y}[\mathrm{mm}]$ \\
\hline A1 & -20 & 0 & C1 & 0 & -20 \\
\hline A2 & -10 & 0 & C2 & 0 & -10 \\
\hline 3 & 0 & 0 & C4 & 0 & 10 \\
\hline A4 & 10 & 0 & C5 & 0 & 20 \\
\hline A5 & 20 & 0 & D1 & 20 & -20 \\
\hline B1 & -20 & -20 & D2 & 10 & -10 \\
\hline B2 & -10 & -10 & D4 & -10 & 10 \\
\hline B4 & 10 & 10 & D5 & -20 & 20 \\
\hline B5 & 20 & 20 & & & \\
\hline
\end{tabular}

\section{RESULTS}

After milling the surface, the values of the roughness parameters were measured at the given points. Arithmetic mean roughness $\mathrm{Ra}$ and maximum height of profile $\mathrm{Rz}$ parameters are reported (the most commonly used parameters in the industry of the indices defined in ISO 4287). The measurements were repeated three times at each point, and the results described in Table 2 give their arithmetic mean.

$$
R_{i}=\left(\sum_{i=1}^{n} R_{i, j}\right) / n \quad(i=a, z)
$$

The values are summarized in Table 2 to correspond with the evaluation. Thus, the numbering of the measuring points, except for plane $\mathbf{A}$, reflects the direction of the front-cutting movement of the tool edge in the workpiece. The 
calculation of the average values over the whole surface is given by Equation (1), where $j=1 \ldots n$ is the number of measuring points. Their results are $\mathrm{R}_{\mathrm{a}}=1.154 \mu \mathrm{m}$, $\mathrm{R}_{\mathrm{z}}=5.275 \mu \mathrm{m}$.

Table 2 - Roughness values in the marked direction planes

\begin{tabular}{|c|c|c|c|c|c|c|c|c|}
\hline \multirow{2}{*}{ No.IPlane } & \multicolumn{4}{|c|}{$\mathrm{R}_{\mathrm{a}}[\mu \mathrm{m}]$} & \multicolumn{4}{c|}{$\mathrm{R}_{\mathrm{z}}[\mu \mathrm{m}]$} \\
\cline { 2 - 9 } & $\mathbf{A}$ & $\mathbf{B}$ & $\mathbf{C}$ & $\mathbf{D}$ & $\mathbf{A}$ & $\mathbf{B}$ & $\mathbf{C}$ & $\mathbf{D}$ \\
\hline $\mathbf{1}$ & 1.10 & 1.56 & 1.53 & 1.50 & 4.94 & 6.84 & 6.77 & 6.50 \\
\hline $\mathbf{2}$ & 1.09 & 1.35 & 1.33 & 1.31 & 4.69 & 5.99 & 5.86 & 5.64 \\
\hline $\mathbf{3}$ & 1.13 & 1.13 & 1.13 & 1.13 & 4.83 & 4.83 & 4.83 & 4.83 \\
\hline $\mathbf{4}$ & 1.05 & 0.77 & 0.83 & 0.79 & 4.64 & 4.38 & 4.75 & 4.38 \\
\hline $\mathbf{5}$ & 1.01 & 1.06 & 1.13 & 1.02 & 4.66 & 5.42 & 5.36 & 5.01 \\
\hline
\end{tabular}

\section{DISCUSSION}

The deviations of the values obtained at the measurement points from the total average are analyzed as given in Equation (2), where $j=1 \ldots n$ is the number of measuring points. These are summarized in Table 3 . The deviation values are plotted in bar graphs (Fig. 2) to assist in the evaluation method.

$$
\Delta R_{i}=R_{i, j}-R_{i} \quad(i=a, z)
$$

Regarding the values of the deviations, it can be said that the parameters $R_{a}$ and $R_{z}$ show the same nature for a given plane. Since the values in the planes $\mathbf{B}$ and $\mathbf{D}$, which are symmetric to plane $\mathbf{C}$, have nearly the same values at the same point number, it can be concluded that one direction is sufficient to be chosen in order to characterize the roughness of the surface in the $45^{\circ}$ direction with minimal deviations.

Table 3 - Deviations of roughness values from total average values

\begin{tabular}{|c|c|c|c|c|c|c|c|c|}
\hline \multirow{2}{*}{ No.IPlane } & \multicolumn{4}{|c|}{$\Delta \mathrm{R}_{\mathrm{a}}[\mu \mathrm{m}]$} & \multicolumn{4}{c|}{$\Delta \mathrm{R}_{\mathrm{z}}[\mu \mathrm{m}]$} \\
\cline { 2 - 9 } & $\mathbf{A}$ & $\mathbf{B}$ & $\mathbf{C}$ & $\mathbf{D}$ & $\mathbf{A}$ & $\mathbf{B}$ & $\mathbf{C}$ & $\mathbf{D}$ \\
\hline $\mathbf{1}$ & -0.06 & 0.40 & 0.37 & 0.35 & -0.33 & 1.56 & 1.50 & 1.23 \\
\hline $\mathbf{2}$ & -0.06 & 0.19 & 0.18 & 0.16 & -0.59 & 0.71 & 0.59 & 0.36 \\
\hline $\mathbf{3}$ & -0.02 & -0.02 & -0.02 & -0.02 & -0.45 & -0.45 & -0.45 & -0.45 \\
\hline $\mathbf{4}$ & -0.10 & -0.39 & -0.32 & -0.36 & -0.63 & -0.89 & -0.53 & -0.89 \\
\hline $\mathbf{5}$ & -0.15 & -0.09 & -0.02 & -0.14 & -0.62 & 0.15 & 0.09 & -0.27 \\
\hline
\end{tabular}

The deviation values are scattered between $\mathrm{R}_{\mathrm{a}}=-0.39 \ldots 0.4 \mu \mathrm{m}$ and $\mathrm{R}_{\mathrm{z}}=-0.89 \ldots 1.56 \mu \mathrm{m}$, which mean significant $(70 \%$ and $47 \%$, respectively) differences. Values in plane $\mathbf{A}$ are close to average (the highest differences from it are $R_{a}=0.15 \mu \mathrm{m}, R_{z}=0.63 \mu \mathrm{m}$ ), for the other planes, the values from the average 
are higher at points $\mathbf{1 ,} \mathbf{2}$ on the entry side, close to it in the middle $\mathbf{3}$ points, and smaller at point $\mathbf{4}$ on the exit side. Within a plane, the variance of the values is maximal in plane $\mathbf{B}\left(\Delta \mathrm{R}_{\mathrm{a}}=0.79 \mu \mathrm{m}, \Delta \mathrm{R}_{\mathrm{z}}=2.45 \mu \mathrm{m}\right)$. The least deviations can be found within plane $\mathbf{A}\left(\Delta \mathrm{R}_{\mathrm{a}}=0.13 \mu \mathrm{m}, \Delta \mathrm{R}_{\mathrm{z}}=0.3 \mu \mathrm{m}\right)$, in the other directions there are differences close to the maximum. Thus, it can be concluded that large variations in the measured roughness values are expected in any examining plane with an angle other than the direction parallel to the feed.
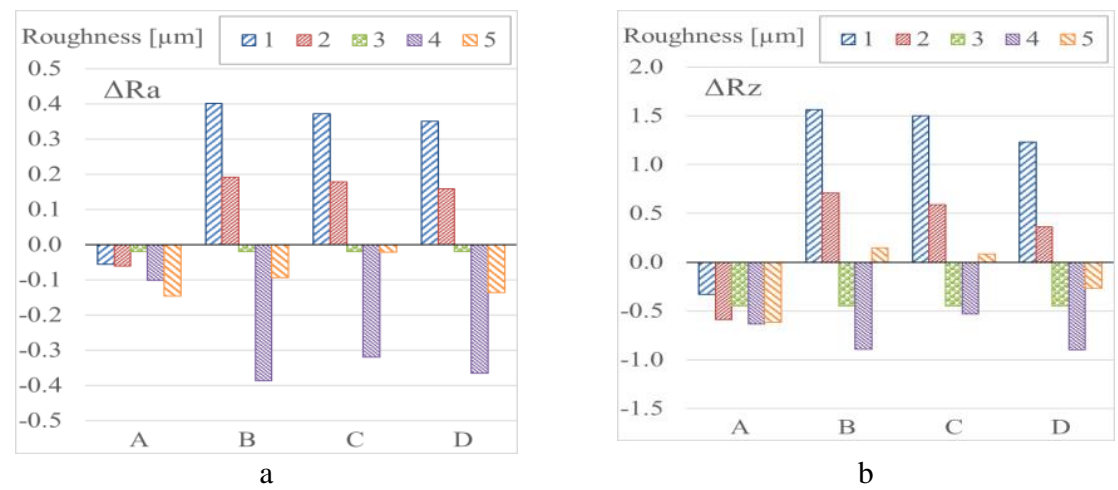

Figure 2-Magnitude of the differences in roughn ess values in the examining planes

A relative increase in the values of point 4 is observed when the angle of the examining plane is closer to plane $\mathbf{C}$. In each plane maximal roughness values are found in point $\mathbf{1}$ on the entry side (all the points of plane $\mathbf{A}$ are fitted to the symmetry plane, so now this is an exception), and with getting further from it, towards the exit side of the surface a decrease can be observed. However, the location of the minimum values is not on the far exit side (at point 5). In each plane except $\mathbf{A}$ it is found that the roughness values continuously decrease in the direction of points $\mathbf{1}$ to $\mathbf{4}$, and then on the far exit side at point 5 they increase to values that are close to the average. Also, on the entry side, the values of points 1 and $\mathbf{2}$ increase the total average, while points $\mathbf{3}$ and $\mathbf{4}$ decrease it. Based on the latter, it can be said that the values of the amplitude roughness parameters are higher on the entry side, where there is up-milling, than on the exit side, where down-milling occurs.

For the values of all points with the same number, it can be seen that if planes with angle $\propto>0^{\circ}$ are considered, they have almost the same value. The common characteristic is that the points with the given number are at the same distance from the plane of symmetry. In this regard, it can be stated that the roughness values of a 
measuring point - for the parameters $\mathrm{R}_{\mathrm{a}}$ and $\mathrm{R}_{\mathrm{z}}$ - are basically determined by how far the point is from the symmetry plane and on which side of the surface.

\section{CONCLUSIONS}

In this paper the change in roughness was examined at different points on the topography along several analysis planes at different angles from the feed direction on a dry face milled steel workpiece surface. At the selected points, the $2 \mathrm{D}$ profile roughness was measured in a direction parallel to and perpendicular to the feed. The findings are as follows.

On the $40 \times 40 \mathrm{~mm}^{2}$ examined area on the symmetrically face milled surface cut with a tool having a nominal diameter of $D_{t}=80 \mathrm{~mm}$, the values of the arithmetic mean height $R_{a}$ and the maximum height of profile $R_{z}$ parameters scattered significantly: the magnitude of them was about $0.8 \mu \mathrm{m}$ and $2.5 \mu \mathrm{m}$, which mean(s) $70 \%$ and $47 \%$ deviations, respectively. As a result, the roughness inhomogeneity of a face-milled surface is considerable, and this needs investigation.

Large deviations in the measured roughness values can be expected in any examining plane with an angle other than the feed direction.

It was found that the magnitude of the roughness values depends on the distance from the symmetry plane and the location of the point on the surface, so in a plane parallel to the feed direction, a small deviation of the values is typically expected.

The highest roughness on the machined surface was measured on the side of the surface where the tool edge enters the workpiece, where the roughness values increased the average. A minimal value was found on the exit side, where the roughness was lower than average. The values measured on the symmetry plane were close to the mean. With this it can be stated that for maximum values it is incorrect to measure the roughness of the face milled surface in the symmetry plane; according to our analysis the maximum value typically occurs on the entry side. Further studies will focus on determining its exact location.

References: 1. Surface Texture Symbols: ASME Y14.36M-1978, American National Standards Institute. 2. Kundrak, J., Felho, C.: 3D roughness parameters of surfaces face milled by special tools, Manufacturing technology vol.16(3) (2016) pp.532-538. 3. Kundrak, J., Felho, C.: Topography of the machined surface in high performance face milling, Procedia CIRP vol.77 (2018) pp.340-343. 4. Felho, C., Kundrak, J.: Characterization of topography of cut surface based on theoretical roughness indexes, Key Engineering Materials vol.496 (2012) pp.194-199. 5. Felho, C., Kundrak, J.: Comparison of Theoretical and Real Surface Roughness in Face Milling with Octagonal and Circular Inserts, Key Engineering Materials vol.581 (2014) pp.360-365. 6. Arizmendi, M., Jiménez, A.: Modelling and analysis of surface topography generated in face milling operations, International Journal of Mechanical Sciences vol.163 (2019) ArtNo.105061. 7. Chuchala, D., Dobrzynski, M., Pimenov, D.Y., Orlowski, K.A., Krolczyk, G., Giasin, K.: Surface roughness evaluation in thin EN AW-6086-T6 alloy plates after face milling process with different strategies, Materials vol.14(11) (2021) ArtNo.3036. 8. Pham, T. 
Nguyen, D., Banh, T., Tong, V.: Experimental study on the chip morphology, tool-chip contact length, workpiece vibration, and surface roughness during high-speed face milling of A6061 aluminum alloy, Proceedings of The Institution of Mechanical Engineers Part B - Journal of Engineering Manufacture vol.234(3) (2020) pp.610-620. 9. Gocke, H.: Optimisation of Cutting Tool and Cutting Parameters in Face Milling of Custom 450 through the Taguchi Method, Advances in Materials Science and Engineering vol.2019 (2019) ArtNo.5868132. 10. Bruni, C., d'Apolito, L., Forcellese, A., Gabrielli, F., Simoncini, M.: Surface roughness modelling in finish face milling under MQL and dry cutting conditions, International Journal of Material Forming vol.1(1) (2008) pp.503-506. 11. Saï, K., Bouzid, W.: Roughness modeling in up-face milling, International Journal of Advanced Manufacturing Technology vol.26 (2005) pp.324-329. 12. Pimenov, D.Y., Hassui, A., Wojciechowski, S., Mia, M., Magri, A., Suyama, D.I., Bustillo, A., Krolczyk, G., Gupta, M.K.: Effect of the relative position of the face milling tool towards the workpiece on machined surface roughness and milling dynamics, Applied Sciences vol.9(5) (2019) ArtNo.842. 13. Nagy, A., Kundrák, J.: Changes in the values of roughness parameters on face-milled steel surface, Cutting \& Tools in Technological Systems vol.92 (2020) pp.85-95.

\title{
Антал Надь, Янош Кундрак, Мішкольц, Угорщина
}

\section{АНАЛІЗ ЗМІНИ ШОРСТКОСТІ ФРЕЗЕРОВАНОЇ ПОВЕРХНІ, ЯКА ВИМІРЮВАЛАСЬ В НАПРЯМКУ $45^{\circ}$ ДО ВЕКТОРА ПОДАЧІ}

\begin{abstract}
Анотація. У иій статті аналізується різниця (неоднорідність) значень шорсткості, виміряних на поверхні заготівки з нелегованої вуглецевої сталі, фрезерованої пластиною у формі паралелограма $\left(\kappa_{r}=90^{\circ}\right)$, залежно від напрямку руху інструменту та відносного положення точок поверхні заготовки, що розглядаються. Характерний розподіл шорсткості $і$ величина відхилень були досліджені шляхом вимірювання у вибраних точках уздовж декількох площин на поверхні, ще характеризується умовами руху заготовки та симетрично розтамованого інструменту, перпендикулярного оброблюваній поверхні, які утворювали подвійні сліди фрезерування. Вибрані точки відзначають лінії із заданими нахилами по відношенню до напрямку подачі, а виміряні їх значення порівнюються. За цими напрямами була отримана величина відмінності у показниках шорсткості. У вибраних точках була виміряна шорсткість $2 D$-профілю у напрямку, паралельному та перпендикулярному вектору подачі. Висновки такі. На досліджуваній площі $40 \times 40$ мм $^{2}$ на симетрично ториево фрезерованій поверхні, обробленій інструментом номінальним діаметром $D_{t}=80$ мм, значення параметрів середньої арифметичної висоти $R_{a}$ та максимальної висоти профілю $R_{z}$ суттево розійшлися: їх величини становили приблизно 0,8 мкм та 2,5 мкм, щчо означає відхилення 70\% та 47\% відповідно. В результаті неоднорідність шорсткості ториево фрезерованої поверхні є значною, і це потребує дослідження. Великі відхилення у виміряних значеннях шорсткості можна очікувати у будь-якій площині дослідження з кутом, відмінним від напряму подачі. Було виявлено, щяо величина значень шорсткості залежить від відстані від площини симетрї та від положення точки на поверхні, тому в площині, паралельній до напряму подачі, зазвичай очікується невелике відхилення значень. Найбільша шорсткість обробленої поверхні була виміряна на тій стороні поверхні, де край інструменту входить у заготовку, де середнє значення шорсткості збільшується. Мінімальне значення було виявлено на вихідній стороні, де шорсткість була нижчою за середню. Значення, виміряні на площчині симетрії, були близькі до середніх. При цььому можна констатувати, щчо для максимальних значень некоректно вимірювати шорсткість фрезерованої торцевої поверхні в плошині симетрії; згідно з нашим аналізом, максимальне значення зазвичай спостерігається на боці входу. Подальші дослідження будуть зосереджені на визначенні його точного розташування.
\end{abstract}

Ключові слова: ториеве фрезерування; шорсткість поверхні; розподіл шорсткості. 